\title{
SPATIAL RELATIONSHIP BETWEEN POPULATION DENSITY AND LAND USE LAND COVER DYNAMICS: A CASE STUDY OF MAGAMBA NATURE RESERVE, WESTERN USAMBARA MOUNTAINS, TANZANIA
}

\author{
Solomon Jeremiah Sembosi \\ Department of Research and Protection \\ Southern Tanzania Elephant Program, \\ Iringa, Tanzania
}

\begin{abstract}
Increase in population density is a critical challenge facing most of the areas where abundance of natural resources is located. Magamba Nature Reserve is that the largest forest fragment remaining within the West Usambara mountain block. According to the national census of 2012 the villages bordering this Nature Reserve were identified to be one of the areas where population is increasing exponentially. It has been claimed the increase in population is a source of changes in forest resources and environment in general. This perception has not been identified due to prior studies done in this area have not explored the relationship between population growth and land use land cover changes. A post-classification change detection method was used to analyze the changes in land use land cover. Administrative level census data of Tanzania was used to identify population density for the villages bordering Magamba Nature Reserve. The results on assessment of land use land cover changes for the period of 1995 to 2015 described the increase in anthropogenic activities. There is an expansion of built-up areas from 36.50 ha $(0.28 \%)$ in 1995 to 1792.92 ha $(13.59 \%)$ in 2015 and agricultural activities from 169.33 (1.28\%) in 1995 to $282.16(2.16 \%)$ in 2015 at the expense of other land cover patterns. This was mainly attributed to demographic changes. In addition, population density was related to changes in agriculture and built-up areas during the study period. Increase in population density was found to be 26274 individuals in 1995 to 80523 individuals in 2015 for the 14 villages surrounding Magamba Nature Reserve. An important observation from this analysis is the increase in population density impacts natural vegetation due to increase in agricultural lands and builtup areas. This highlights the necessity of protecting natural resources by improving the management strategies to cope with the fast-changing world.
\end{abstract}

Keywords - Population density, Land use land cover change, Magamba Nature Reserve, Tanzania

\section{INTRODUCTION}

Increase in population density is a critical challenge facing most of the developing countries especially in rural areas [1, $15,5]$. This is due to most of the individuals in developing countries still leaves in rural areas and thus making these areas more susceptible to rapid population increase [6]. This has resulted in spatial dimension and increase in demand for land to accommodate the increased number of people. Apart from that the related requirements for the increased population are development of infrastructure facilities and built-up areas including settlement areas. Therefore, this has resulted in mismatch between the available land and individuals needs and thus enhancement in degradation of natural vegetation especially forest resources.

Around the world about 1.4 billion people lack accesses to electricity and $85 \%$ of them are found in rural areas [12]. This has influence on use of forest resources as alternative source of energy this includes the need for firewood as well as building materials [11]. In most developing countries such as Tanzania uncontrolled growth of population in rural areas and inadequate infrastructure facilities will lead to increase in irreversible changes of land use/land cover. For instance, decrease in natural forests due to a number of rural settlers still depends on forest resources for their daily life [9, 17, 22]. This contributes to environmental changes which has a large impact on biodiversity loss, ecosystem degradation and fragmentation $[16,14,4,20,7]$.

Magamba Nature Reserve has been one of the major location in Western Usambara Mountains experiencing changes in natural vegetation. Some of the claims regarding to changes in 


\section{International Journal of Engineering Applied Sciences and Technology, 2019 \\ Vol. 4, Issue 4, ISSN No. 2455-2143, Pages 211-217 \\ Published Online August 2019 in IJEAST (http://www.ijeast.com)}

vegetation identified population of the individuals inhabiting around the reserve have increased. This has resulted to illegal activities and encroachments but also expansion of settlement and agricultural lands. This area is more susceptible to changes in land use land cover as it is located in Lushoto district in which is among the most densely populated districts in Tanzania, compared to the national average of 39 persons per $\mathrm{km} 2[18,19]$. On the other side this claim has not been proved quantitively and nevertheless population have not been confirmed as the main factor. Therefore, this study aims at quantifying the population of the villages around the nature reserve and link them with changes in land use land cover in and around the reserve. In order to identify the relationship between population increase and its influence on changes of land use land cover. Understanding of land use land cover changes is crucial for sustainable management of this unique natural resource as it will allow decision makers to take a broader view of rural areas development and expansion. But also, it will increase awareness to local authorities as they are hardly able to manage the pace of rural development and its impact on environment due to lack of clear awareness of the main causes of changes on natural resources.

\section{MATERIALS AND METHODS}

\section{A. Description of Study Area}

Magamba Nature Reserve is located in Lushoto district at $4^{\circ} 40^{\prime} \mathrm{S}$ and $38^{\circ} 15^{\prime} \mathrm{E}$ (Figure 1). The area is characterized by cool weather with variation between $15^{\circ} \mathrm{C}$ and $30^{\circ} \mathrm{C}$ for the whole year and $800 \mathrm{ml}$ of rainfall per annum. The forest is surrounded in close proximity by 17 villages namely; Magamba village on the east, Kwesimu, Kwembago and Irente on the South-East, Lukozi, Viti and Hambalawei on the Northern side, Kinko-Mpanda, Kireti and Migambo on the North- East, Mavumo, Gologolo and Manolo on the North West, Nywelo and Mkunki on the West, Mazinde and Mkumbara villages border the reserve on the Southern part. The topography of this land is undulating, and the forest has a wide range of mountains. The altitude varies between 1650 and 2300 m.a.s.1. Kwahondo peak dominates the Magamba area raising to about $2300 \mathrm{~m}$.a.s.l. The land drops away sharply in the West of Shume on the edge of West Usambara scarp. Slopes are steep to gently undulating and are intersected at their base by narrow flat valleys [21, 19].

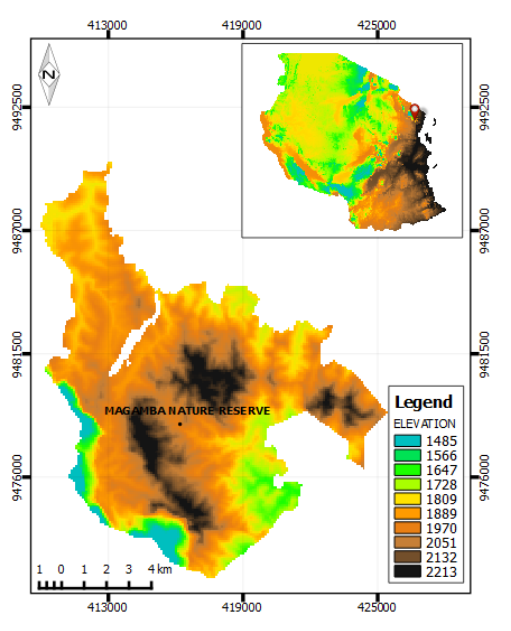

Fig. 1. A map of Tanzania showing location of the study area

\section{B. Data Collection}

Population data of the villages bordering Magamba Nature Reserve were acquired from the village offices, government website of Tanzania (www.geohive.com) and nature reserve office. Given that in Tanzania national census are conducted at different periods the population during the inter-census periods were estimated for each village after being confirmed by overlaying the nature reserve boundary on the Tanzania villages shapefile. Therefore, interpolation and/or extrapolation was done to fill the gaps for the periods in which census was not conducted in the country.

Exponential growth (Interpolation and/or extrapolation) estimation formula is shown below;

Growthrate $(\mathrm{r})=\left(\left(\frac{\mathrm{pl}}{\mathrm{pb}}\right)^{1 / n}\right)-1$

Where $P l=$ population at launch year; $P b=$ population at base year and $n$ is period of time

$\mathrm{pt}=\mathrm{pb} *(1+r)^{z}$

Where $P t=i$ is the population in the target year, and $z$ is the number of years in the projection horizon [2].

In this study, Landsat satellite images for the years 1995, 2008 and 2015 obtained from Unites States Geological Survey (USGS) Data Interface from the Global Visualization Viewer (Glo Vis) at HTTP: glovis.usgs.gov were used. Global positioning system (GPS) was used to collect ground control points for verification of land use land cover on site. Therefore, land use land cover patterns were attained from the satellite images scenes of 1995 TM, 2008 TM and 2015 OLI. All images were selected from the dry season for easy interpretation of different cover types and their spatial resolution was $30 \mathrm{~m}$. 


\section{International Journal of Engineering Applied Sciences and Technology, 2019 \\ Vol. 4, Issue 4, ISSN No. 2455-2143, Pages 211-217 \\ Published Online August 2019 in IJEAST (http://www.ijeast.com)}

\section{Data analysis}

Population cover relationship was analyzed, based on transition map that was prepared for the periods 1995 to 2008 and from 2008 to 2015 using the MMQGIS plugin in Quantum GIS. The population map was prepared by joining the population data to each village shapefile that falls near Magamba Nature Reserve. Therefore, for the population land use land cover relationship selection by location and overlaying was used.

Different land use land covers were identified based on satellite images for the three studied periods (i.e. 1995, 2008 and 2015). Thereafter satellite images were processed using open source software (Q-GIS). Images were rectified to the UTM projection, Clarke 1880 spheroid, Zone 37s and Arc 1960 datum. An area of interest was selected given Magamba Nature Reserve was encompassed. The area of interest was used to subset the three Landsat images of 1995, 2008 and 2015 for the study area. Satellite images were classified to produce different land use land cover types and analyzed to identify changes that have occurred in and around the study area. Latest google aerial photograph of 2015 and topographic map of the study area at a scale of 1:50,000 were used to support image interpretation and the whole classification process.

\section{RESULTS AND DISCUSSION}

\section{Population increase}

Increase in human population in Eastern Arc Mountains have been attracted by the high annual rainfall, soils and natural resources this biodiversity hotspot is endowed with [8]. Lushoto is among of the districts in Eastern Arc Mountains with its rural areas being heavily populated. According to the National Bureau of Statistics in the human population census of 2012 average population density of 120 persons per $\mathrm{km} 2$ in Lushoto district was quite twice as high as the national average for mainland Tanzania [18]. Increase in human population has led to decline in natural resources especially forest as a result of over-exploitation [3]. Figure 2 indicates the increasing trend of the human population in villages surrounding Magamba Nature Reserve from 1995 to 2015.

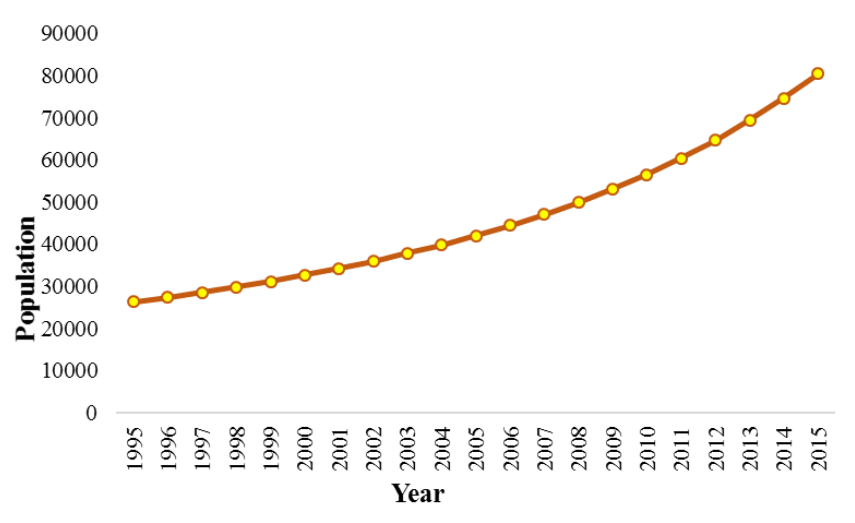

Fig. 2. Total population per year of the villages bordering Magamba Nature Reserve, Tanzania

A further look at the seventeen (17) individual villages has been presented by figure 3. Manolo village has higher population compared to other villages with a population of 139176 (14\%) individuals. Followed by Lukozi with the total population of $11 \%$ out of the population for all the villages. Other villages share the remaining $75 \%$ of the total population while the smallest population appears to be in Kwesimu village with the total of 12605 inhabitant's equals to $1 \%$ of the whole population.

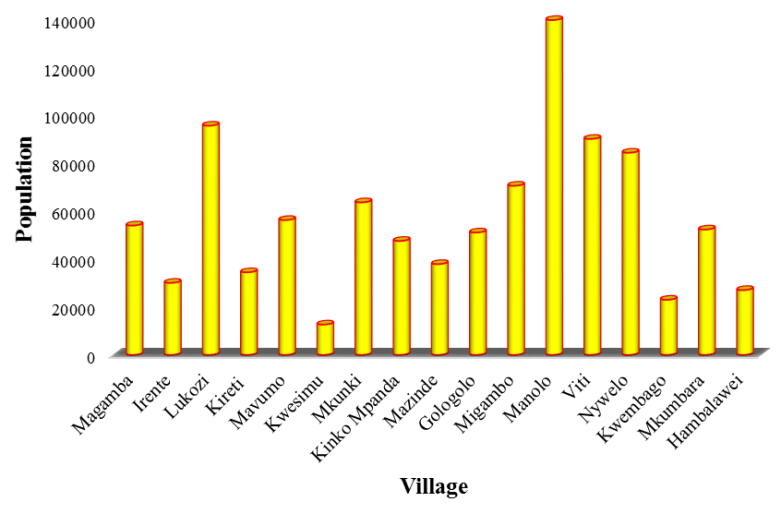

Fig. 3. Population of each village adjacent to Magamba Nature Reserve, Tanzania

\section{Population density of the villages around Magamba Nature Reserve}

The population density of the villages surrounding Magamba Nature Reserve are presented in terms of square kilometers whereby they are presented from 1995 to 2008, 2008 to 2015 and from 1995 to 2015 as Figure 3, 4 and 5 indicated. This quantitative data was derived based on the available census data of 2002 and 2012. Furthermore, the qualitative data obtained from the household's response and key informants were very useful to understand the results in an increase of the 


\section{International Journal of Engineering Applied Sciences and Technology, 2019 \\ Vol. 4, Issue 4, ISSN No. 2455-2143, Pages 211-217 \\ Published Online August 2019 in IJEAST (http://www.ijeast.com)}

population density in the villages surrounding Magamba Nature Reserve.

The increase in population for the villages bordering Magamba Nature Reserve brings a confirmation on the increase in built-up areas and agricultural land as revealed in the results of changes in land use land cover in and around the reserve.

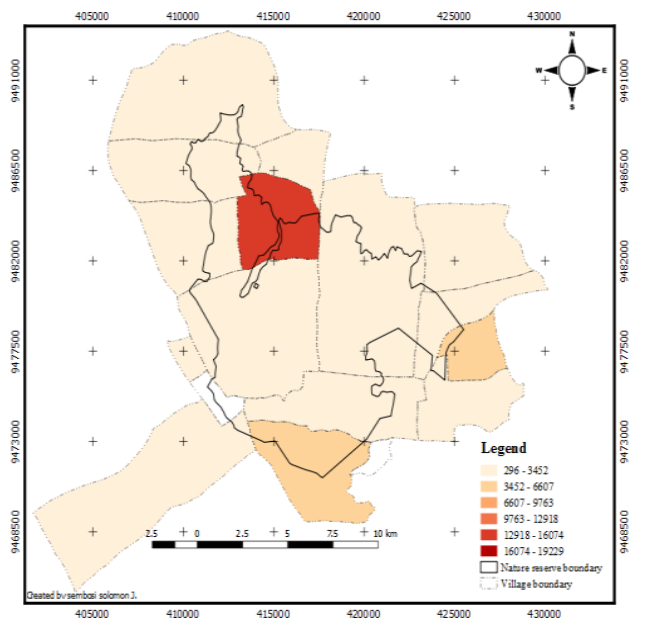

Fig. 3. Population densities per square kilometers of the villages around Magamba Nature Reserve for the period 1995 - 2008, Tanzania

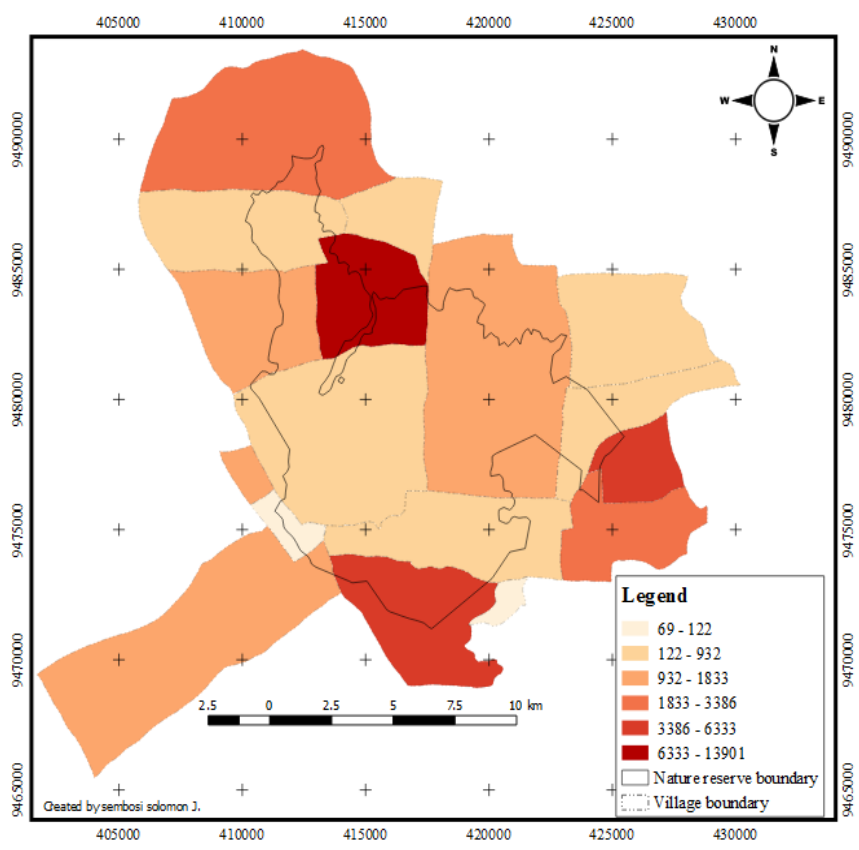

Fig. 4. Population densities per square kilometers of the villages around Magamba Nature Reserve for the period 2008 2015, Tanzania

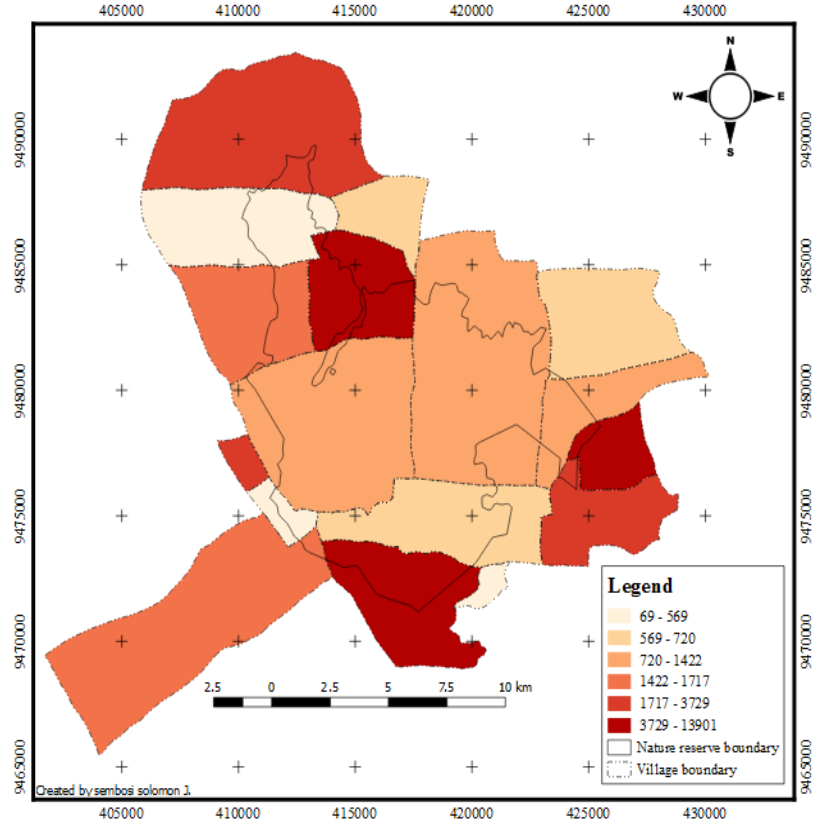

Fig. 5. Population densities per square kilometers of the villages around Magamba Nature Reserve for the period 1995 2015, Tanzania

\section{Land Use Land Cover Distribution for the period 1995, 2008 and 2015}

For the year 1995 seven land use land cover were identified whereby the major land cover was natural forest which accounts for 6841.77 ha $(51.89 \%)$, but also 1441.37 ha $(10.93$ $\%)$ for plantation forest, 1379.46 ha $(10.46 \%)$ for grassland, 1057.73 ha $(8.03 \%)$ for shrub-land, 2465.75 ha $(18.69 \%)$ for woodland, 169.33 ha $(1.28 \%)$ for agricultural land and builtup area was 36.50 ha $(0.28 \%)$. It is being evident that during this period the areas for agriculture and built-up were very small revealing the nature reserve was not that much impacted by human activities as indicated in figure 6 .

In 2008 the area covered by natural forest, grassland, shrubland and woodland declined by 6062.06 ha (45.97\%), 822.61 ha $(6.24 \%), 358.95$ ha $(2.73 \%)$ and 1737.77 ha $(13.18 \%)$ respectively. On the other side plantation forest increased to 2390.59 ha $(18.13 \%)$ but also agricultural land together with built-up area enlarged to 902.54 ha $(6.84 \%)$ and 911.56 ha $(6.91 \%)$. This result suggests human activities within and/or around the nature reserve were active during this period. 


\section{International Journal of Engineering Applied Sciences and Technology, 2019 \\ Vol. 4, Issue 4, ISSN No. 2455-2143, Pages 211-217 \\ Published Online August 2019 in IJEAST (http://www.ijeast.com)}
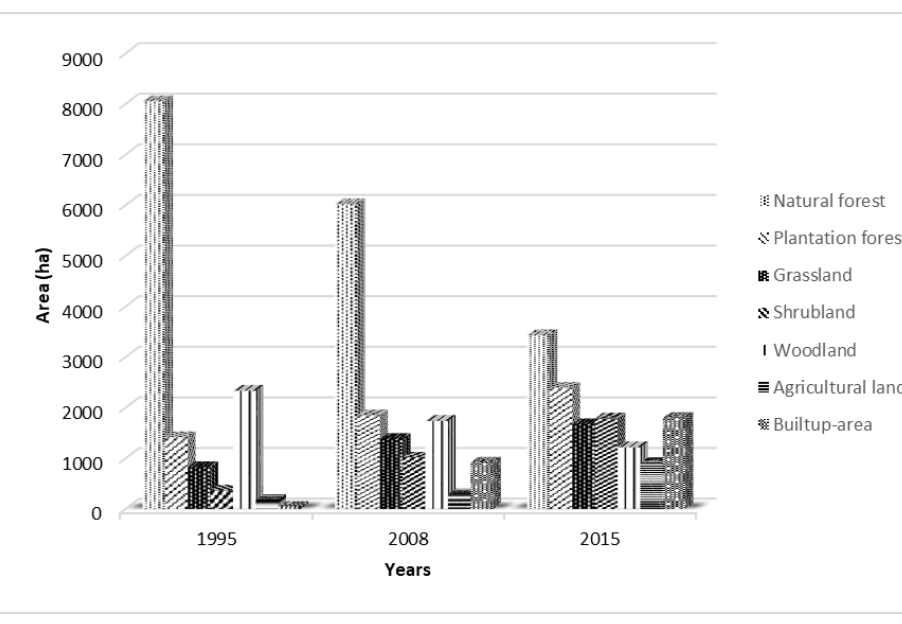

\begin{tabular}{|l|c|c|c|c|c|c|c|c|}
\hline & & & & & & & & \\
\hline $\begin{array}{l}\text { Natur } \\
\text { al } \\
\text { forest }\end{array}$ & 6841.50 & 51.88 & 6062.06 & 45.97 & -779.44 & -5.91 & -59.96 & -0.45 \\
\hline $\begin{array}{l}\text { Planta } \\
\text { tion } \\
\text { forest }\end{array}$ & 1413.97 & 10.72 & 2390.59 & 18.13 & 976.62 & 7.41 & 75.12 & 0.57 \\
\hline $\begin{array}{l}\text { Grassl } \\
\text { and }\end{array}$ & 1379.46 & 10.47 & 822.61 & 6.24 & -556.85 & -4.23 & -42.83 & -0.33 \\
\hline $\begin{array}{l}\text { Shrub } \\
\text { land }\end{array}$ & 1011.95 & 7.67 & 358.95 & 2.73 & -653 & -4.94 & -50.23 & -0.38 \\
\hline $\begin{array}{l}\text { Wood } \\
\text { land }\end{array}$ & 2333.37 & 17.7 & 1737.77 & 13.18 & -595.6 & -4.52 & -45.82 & -0.35 \\
\hline $\begin{array}{l}\text { Agric } \\
\text { ultural } \\
\text { land }\end{array}$ & 169.33 & 1.28 & 902.54 & 6.84 & 733.21 & 5.56 & 56.40 & 0.43 \\
\hline $\begin{array}{l}\text { Built- } \\
\text { up } \\
\text { area }\end{array}$ & 36.50 & 0.28 & 911.56 & 6.91 & 875.06 & 6.63 & 67.31 & 0.51 \\
\hline $\begin{array}{l}\text { Total } \\
\text { area }\end{array}$ & 13186.0 & 100 & 13186.0 & 100 & & & & \\
\hline
\end{tabular}

Fig. 6. Distribution in land use land cover within and around Magamba Nature Reserve between 1995 and 2015, Tanzania

In 2015 there was more decrease in natural forest such that only 4596.36 ha $(34.86 \%)$ remained while the decrease in plantation forest and woodland accounts for 1845.91 ha (13.99 $\%)$ and 1216.34 ha $(9.22 \%)$. Other land use land cover accounts for 1670.63 ha $(12.67 \%)$ for grassland, 1781.76 ha $(13.51 \%)$ for shrub-land, agricultural land 282.16 ha $(2.16 \%)$ which decreased compared to the year 2008 indicating some management activities were established to restore the degraded areas as a result of agricultural activities. Unfortunately, built-up area increased to 1792.92 ha (13.59 \%) indicating increase in need of land for settlement by the local communities living around Magamba Nature Reserve due to increased number of individuals inhabiting around and within the nature reserve boundaries.

Apart from all that changes in cover area and the rate of changes for the period between 1995 to 2015 in and around the reserve the results were identified as indicated in table 1 . Plantation forest, agricultural land, and built-up area increased at a rate of 75.12 ha/year (0.57\%/year), $56.40 .43 \mathrm{ha} /$ year $(0.43 \% / y e a r)$ and $67.31 \mathrm{ha} /$ year $(0.51 \% / y e a r)$ respectively over an average period of 13 consecutive years (i.e.1995 and 2008). Natural forest, grassland, shrub-land and woodland decreased consistently at a rate of -59.96 ha/year ($0.45 \% /$ year $),-42.83 \mathrm{ha} /$ year $(-0.33 \% /$ year $),-50.23 \mathrm{ha} /$ year ($0.38)$ and -45.82 ha/year (-0.35).

Table 1. Cover area, changed area and the rate of change between 1995 and 2008 for the study area

\begin{tabular}{|c|c|c|c|c|c|c|c|c|}
\hline \multicolumn{2}{|l|}{ Land use/cover in 1995 } & \multicolumn{3}{|c|}{ Land use/cover in 2008 } & \multicolumn{3}{|c|}{$\begin{array}{c}\text { Land use/cover change } \\
(1995-2008)\end{array}$} \\
\hline $\begin{array}{c}\text { Cover } \\
\text { class }\end{array}$ & $\begin{array}{c}\text { Area } \\
\text { (ha) }\end{array}$ & $\begin{array}{c}\% \\
\text { cover }\end{array}$ & $\begin{array}{c}\text { Area } \\
\text { (ha) }\end{array}$ & $\begin{array}{c}\% \\
\text { cover }\end{array}$ & $\begin{array}{c}\text { Area } \\
\text { change } \\
\text { (ha) }\end{array}$ & $\begin{array}{c}\% \\
\text { cover } \\
\text { chang } \\
\text { e }\end{array}$ & $\begin{array}{c}\text { Annua } \\
\text { rate } \\
\text { of } \\
\text { chang } \\
\text { e } \\
\text { (hayr }\end{array}$ & $\begin{array}{c}\% \text { Annu } \\
\text { al rate } \\
\text { of } \\
\text { change } \\
\left(\% r^{-1}\right)\end{array}$ \\
\hline
\end{tabular}

For the period between 2008 and 2015, the results are defined in Table 2. The grassland increased at a rate of 121.15 ha/years (0.92\%/year), shrub-land increased at a rate of 203.26 ha/year (1.54\%/year), built-up area increased at a rate of $125.91 \mathrm{ha} /$ year $(0.95 \% /$ year $)$ for the average period of 7 years (i.e. 2008 and 2015). Moreover, in this period agricultural land decreased to -620.38 ha/year $(-4.68 \%)$ with the rate of change of $-88.63 \mathrm{ha} /$ year $(-0.67 \% /$ year $)$ this results reveals that a large area has been converted to built-up areas.

Table 2. Cover area, changed area and the rate of change between 2008 and 2015 for the study area

\begin{tabular}{|c|c|c|c|c|c|c|c|c|}
\hline \multicolumn{3}{|c|}{ Land cover in 2008} & \multicolumn{3}{|c|}{ Land cover in 2015} & \multicolumn{3}{|c|}{$\begin{array}{l}\text { Land cover change (2008 - } \\
\text { 2015) }\end{array}$} \\
\hline Cover class & $\begin{array}{r}\text { Area } \\
\text { (ha) }\end{array}$ & $\begin{array}{r}\% \\
\text { cover }\end{array}$ & $\begin{array}{r}\text { Area } \\
\text { (ha) }\end{array}$ & $\begin{array}{r}\% \\
\text { cover }\end{array}$ & $\begin{array}{r}\text { Area } \\
\text { change } \\
\text { (ha) }\end{array}$ & $\begin{array}{r}\% \\
\text { cover } \\
\text { change }\end{array}$ & $\begin{array}{c}\text { Annual } \\
\text { rate of } \\
\text { change } \\
\text { (hayr }\end{array}$ & $\begin{array}{l}\text { \%Annual } \\
\text { rate of } \\
\text { change } \\
\left(\% \mathrm{yr}^{-1}\right)\end{array}$ \\
\hline $\begin{array}{l}\text { Natural } \\
\text { forest }\end{array}$ & 6062.06 & 45.97 & 4596.36 & 34.86 & -1465.7 & -11.11 & 209.39 & -1.59 \\
\hline $\begin{array}{l}\text { Plantation } \\
\text { forest }\end{array}$ & 2390.59 & 18.13 & 1845.91 & 13.99 & -544.68 & -4.14 & -77.81 & -0.59 \\
\hline Grassland & 822.61 & 6.24 & 1670.63 & 12.67 & 848.02 & 6.43 & 121.15 & 0.92 \\
\hline Shrub land & 358.95 & 2.73 & 1781.76 & 13.51 & 1422.81 & 10.78 & 203.26 & 1.54 \\
\hline Woodland & 1737.77 & 13.18 & 1216.34 & 9.22 & -521.43 & -3.96 & -74.49 & -0.57 \\
\hline $\begin{array}{l}\text { Agricultural } \\
\text { land }\end{array}$ & 902.54 & 6.84 & 282.16 & 2.16 & -620.38 & -4.68 & -88.63 & -0.67 \\
\hline $\begin{array}{l}\text { Built-up } \\
\text { area }\end{array}$ & 911.56 & 6.91 & 1792.92 & 13.59 & 881.36 & 6.68 & 125.91 & 0.95 \\
\hline Total area & 13186.08 & 100 & 13186.08 & 100 & & & & \\
\hline
\end{tabular}




\section{International Journal of Engineering Applied Sciences and Technology, 2019 \\ Vol. 4, Issue 4, ISSN No. 2455-2143, Pages 211-217 \\ Published Online August 2019 in IJEAST (http://www.ijeast.com)}

\section{Relationship between population growth and changes on land use land cover patterns}

From this study population is increasing fast and a large part of the nature reserve is converted to agricultural and built-up areas. This identification corresponds to [10] as documented a large percent of the population in sub-Saharan countries depends on agriculture as the main source of income and thus causing it to be one of the major drivers of land cover changes. Moreover [13] declared insufficient resources and population increase to be the main causes of changes in land uses in tropics.

Population of the villages bordering Magamba Nature Reserve are increasing at high rate as indicated in figure 2 . This has been identified throughout the study period and matches the dominancy of both agriculture and built-up areas. This approves that population increase had a high influence on the expansion of built-up and agricultural areas.

Relating the loss and gain of both agriculture and built-up areas with other land use land cover, the gain of agriculture and built-up areas was constantly much higher than other land use land cover likewise the net loss was low compared to other land use land cover in and around the reserve. Given, the conversion of different land use land cover to agriculture and built-up area cover classes were picked for analysis of its relationship with population dynamics at the village level. As indicated in figure 7 high population density villages are located in the north and south parts of the nature reserve. Notably, the major conversion from various land use land cover to agriculture occurred more in the northern parts of the reserve where there is high population as indicated in figure 2 as one of the village with higher population is Manolo which is on the northern side of the reserve. Moreover, the conversion from different land use land cover to built-up areas are located in different parts around the nature reserve although still the larger part converted to built-up areas and or agriculture are the places with the higher population density.

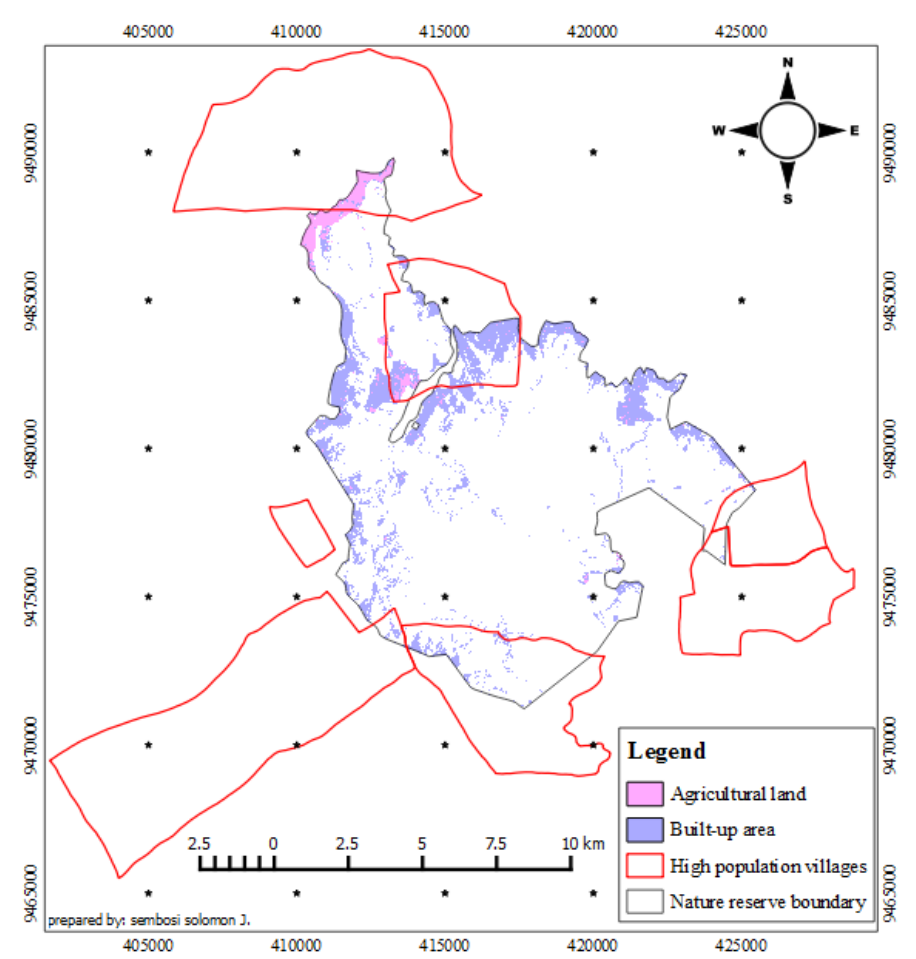

Fig. 7. High population density villages and transition in land use land cover patterns

\section{CONCLUSION}

Increase in population for the villages bordering Magamba Nature Reserve enhance increase in agricultural activities, establishment of settlements but also conversion of one type of vegetation to another due encroachment and illegal activities such as lumbering and logging. The study found them to be the main changes and drivers of forest degradation in and around the reserve. This indicates the future of this endemic ecosystem is in critical danger given the impacts due to increase in population won't be attempted.

\section{ACKNOWLEDGEMENT}

The author acknowledges the enthusiastic cooperation of Magamba Nature Reserve and the surrounding villages.

\section{REFERENCES}

[1] Allen, J. C., \& Barnes, D. F. (1985). "The Causes of Deforestation in Developing Countries", Annals of the Association of American Geographers, vol. 75, no. 2, pp. 163-184.

[2] Berakhi, R. O. (2013). "Implication of human activities on land use land cover dynamics in Kagera catchment, East Africa.", Masters, Southern Illinois 121pp. 


\section{International Journal of Engineering Applied Sciences and Technology, 2019 \\ Vol. 4, Issue 4, ISSN No. 2455-2143, Pages 211-217 \\ Published Online August 2019 in IJEAST (http://www.ijeast.com)}

[3] Braslow J. and Cordingley J. (2016). Participatory mapping in Lushoto district, Tanzania. A case study. International Center for Tropical Agriculture (CIAT). 18 p.

[4] Carlson, T. N., \& Arthur, S. T. (2000). "The impact of land use - land cover changes due to urbanization on surface microclimate and hydrology: a satellite perspective", Global and Planetary Change, vol. 25, no. 1-2, pp. 49-65.

[5] Cohen, B. (2006). "Urbanization in developing countries: Current trends, future projections, and key challenges for sustainability", Technology in Society, vol. 28, no. 1-2, pp. 63-80.

[6] Ellis, F. (2000). Rural livelihoods and diversity in developing countries. Oxford university press.

[7] Foley, J.A., DeFries, R., Asner, G.P., Barford, C., Bonan, G., Carpenter, S.R., Chapin, F.S., Coe, M.T., Daily, G.C., Gibbs, H.K. and Helkowski, J.H. (2005). "Global Consequences of Land Use", Science, vol. 309, no. 5734, pp. 570-574.

[8] German, L. A., Mowo, J., Amede, T., and Masuki, K. (Eds.). (2013). Integrated Natural Resource Management in the Highlands of Eastern Africa from Concept to Practice. Ottawa: Taylor and Francis

[9] Ghazi, P., Barrow, E., Monela, G., \& Mlenge, W. (2005). The wealth of the poor: managing ecosystems to fight poverty. Washington, D.C.: World Resources Institute, pp. 131-138.

[10] Henry, M., Maniatis, D., Gitz, V., Huberman, D., and Valentini, R. (2011). "Implementation of REDD+ in subSaharan Africa: state of knowledge, challenges and opportunities", Environment and Development Economics, vol. 16, no. 4, pp. 381-404.

[11] Inman, K. (1993"Fueling expansion in the third world: population, development, debt, and the global decline of forests," Society \& natural resources, vol. 6, no. 1, pp. 17-39.

[12] Kaygusuz, K. (2012). "Energy for sustainable development: A case of developing countries," Renewable and Sustainable Energy Reviews, vol. 12, no. 2, pp. 1116-1126.

[13] Lambin, E. F., Geist, H. J., \& Lepers, E. (2003). "Dynamics of land-use and land-cover change in tropical regions," Annual review of environment and resources, vol. 28, no. 1, pp. 205-241.

[14] Mass, J. F. (1999). "Monitoring land-cover changes: a comparison of change detection techniques. "International journal of remote sensing, vol. 20, no. 1, pp. 139-152.

[15] McMichael, A. J. (2000). "The urban environment and health in a world of increasing globalization: issues for developing countries. Bulletin of the World Health Organization, vol. 78 no. 9, pp. 1117-1126.

[16] Meyer, W. B., and Turner, B. L. (1992). "Human population growth and global land-use/cover change".
Annual review of ecology and systematics, vol. 23, pp. 3961.

[17] Monela, G. C., S. A. O. Chamshama, R. Mwaipopo, and D. M. Gamassa. 2005. "A Study on the Social, Economic and Environmental Impacts of Forest Landscape Restoration in Shinyanga Region, Tanzania.," Forestry and Beekeeping Division of the Ministry of Natural Resources and Tourism, United Republic of Tanzania, and IUCN-The World Conservation Union Eastern Africa Regional Office, Dar-es-salaam, Tanzania, pp. 17-205.

[18] NBS (National Bureau of Statistics). (2013). Population Distribution by Administrative Areas. National Bureau of Statistics, Ministry of Finance, Dar es Salaam.

[19] Ralaizafisoloarivony, N. A., Kimaro, D. N., Kihupi, N. I., Mulungu, L. S., Leirs, H., Msanya, B. M., and Gulinck, H. (2014). "Vegetation habitats and small mammals in a plague endemic area in Western Usambara Mountains, Tanzania". Tanzania journal of health research, vol. 16 no. 3. pp 194-205.

[20] Southworth, J., Munroe, D., \& Nagendra, H. (2004). "Land cover change and landscape fragmentation comparing the utility of continuous and discrete analyses for a western Honduras region". Agriculture, ecosystems \& environment, vol. 101 no. 2. pp 185-205.

[21] URT (2003). Resource Economic analysis of Catchment forest reserves in Tanzania. Ministry of Natural Resources and Tourism, Forestry and Beekeeping Division. Dar es salaam.

[22] Vedeld, P., Angelsen, A., Bojö, J., Sjaastad, E., \& Berg, G. K. (2007). "Forest environmental incomes and the rural poor". Forest Policy and Economics, vol. 9 no. 7 , pp. 869-879. 